\title{
Reading the Signs: A Brief Portrait of West Sumatra Democracy in the News Headline Discourse
}

\author{
Agustina $^{1}$, Muhammad Adek ${ }^{2}$ \\ ${ }^{1,2}$ Department of Indonesian Language and Literary Studies, Faculty of Languages and Arts, Universitas Negeri Padang, Indonesia \\ Email: marximalize@fbs.unp.ac.id
}

Issue Details

Issue Title: Issue 3

Received: 08 February, 2021

Accepted: 19 March, 2021

Published: 22 May, 2021

Pages:- 1804 - 1813

Copyright (C 2021 by author(s) and Linguistica Antverpiensia

\begin{abstract}
Portraits of the implementation of democracy in a government can be seen from various parameters, one of which is the event report recorded in the daily mass media coverage. This study aims to examine the democratic portraits of West Sumatra province that were presented through the local newspaper Singgalang during the publication period throughout 2016. This study is significant for further investigation because West Sumatra's Democracy Index for that year was categorized as "the lowest." This study includes Critical Discourse Analysis, which focuses on examining the aspects of language that reflect the power relations between the government and the people. The analysis results imply that the Singgalang newspaper can present the face of West Sumatra democracy through titles that describe the actual situation and relationship between the government and citizens. This finding is in line with the Central Bureau of Statistics findings, which indicate the poor implementation of democracy in the province of West Sumatra.
\end{abstract}

\section{Keywords}

Critical Discourse Analysis, Democracy Index, West Sumatra

\section{Introduction}

The capacity of the mass media in shaping public perceptions in viewing various issues is undeniable [1]. The mass media (print and electronic) can shape opinions amid society and determine the boundaries of what can be discussed and how it can be discussed [2]. This process is possible because the mass media has been established to be trusted as a source of valid and comprehensive information. The mass media is considered to have the credibility and neutrality needed by society in understanding essential events and incidents [3]. Consequently, the news in the mass media has considerable potential in changing a situation and dynamics in society.

Based on its history, the mass media has been regarded as a window of information for the general public from centuries ago. As an effective mouthpiece for information, several interested parties have long used the mass media to realize their political agendas [4]. For example, in Indonesia, how activist Ahmad Rivai utilized the Bintang Hindia newspaper (1902-1907) to raise awareness of Indonesian natives to form an intellectual movement through the slogan "kemajuan" (progress) as the primary capital of the national movement [5]. Rivai employed this vernacular newspaper to make people aware of the position and existence of the Indonesian people as the "Indies Nation" and the "Indies Children," which subsequently developed into the Indonesian [6]. With such a strategic capacity, the mass media are always expected to make an essential contribution to political and democratic education for the people.

However, in its development, the mass media in Indonesia are not always accessible and 
free in performing their work, especially disseminating information (information spreading). The government or the authorities have realized the great potential of the mass media and have unique ways to weaken it, such as censorship, submission, banning, and even forced closure. This can be seen from how Sukarno's guided democracy (1959-1965) forced several newspapers to submit and be loyal to the government through the "Supreme Warlords Guidelines for the Indonesian Press" published on October 12, 1960 [7]. The mass media industry felt worse off when it entered the New Order phase (1966-1998). During this period, the control of the mass media by the government was carried out in a systematic and structured manner, among others by limiting the issuance of licenses, controlling news texts, and controlling the career paths of journalist practitioners [8], [9]. Through this mechanism, the role of the mass media is reduced to being merely a tool for the interests of the state (State Apparatus) [10].

Several years before the collapse of the New Order regime, the mass media in Indonesia began to show their actual role and contribution [11]. The mass media have begun to dare to become watchdogs and even whistleblowers such as Indonesia Raya, Sinar Harapan, Detik, Editor, and Tempo [12]. Several media analysts said that the Reformasi movement would never have happened if it had not been initiated by a mass media revolution (primarily commercial ones) [Gazali, 2003]. After the Reformation, the emergence of new mass media (mainly based on visuals and the internet) became increasingly unstoppable and vital, thus strengthening the ties of production-distribution-consumption of information to the public.

Uniquely, the massive media revolution that occurred in Indonesia was only centered on the island of Java. Regions other than Java have not experienced significant development [13]. People in West Sumatra, for example, still rely on the printed mass media (such as newspapers) as a window of information, especially about the developments and dynamics of state life that occur in the province. Consideration of capital and resource factors makes most people continue to consume information through articles published in newspapers as the primary choice. News coverage in the newspapers is still seen as a reflection that is relevant to the facts and realities that have occurred in West Sumatra.

The above factors also become the consideration of the Central Bureau Agency (later BPS) in assessing the democratic performance of the West Sumatra provincial government through analysis of local newspaper texts. In the year 2016 calculations, the Democracy Index Score of West Sumatra province gets the lowest score and labels it as a "bad" category [14]. This is quite peculiar because, during that period, West Sumatra did not experience significant political, social, or cultural turbulences. In a separate statement, the provincial and city governments agreed to refute the findings of BPS and remained adamant that the situation and implementation of democracy in West Sumatra remained as conducive as before [15].

According to BPS records, the trend of democracy in the province of West Sumatra is relatively fluctuating. For example, in 2009, the Democracy Index of West Sumatra was in the "medium" category, but in 2013 it became terrible, then 2015 was in the medium category, and 2016 became terrible again. The results of this calculation were further exacerbated by the existence of several reports that showed violations of democratic values. For example, there have been two cases of violations of religious freedom in the prohibition of Christmas celebrations [16] and the imposition of a headscarf for non-Muslim 
students [17] in recent times.

Since the enactment of the Regional Autonomy Law in 1999, West Sumatra has become one of the provinces that has aggressively restored its political authority following local wisdom, namely Adat based on Religion, and Religion refers to the Holy Scriptures (ABS-SBK). Some policies to support establishing a regional government based on "Nagari" were issued to restore the ideal democratic climate in West Sumatra [18]. This phenomenon became known as the "Babaliak ka Nagari" (Back to Village), which was covered by the West Sumatra provincial regulation no. 9 of 2000 [19].

However, in its implementation, local democracy under the umbrella of regional autonomy has not shown any signs of improvement, especially in performing democratic values. Blackwood [20] states that democracy, especially related to gender equality in West Sumatra, is still limited to myth and symbolism in historical text. Valentina, Kusdarini dan Putera[21] also claims that the development of local democratization in West Sumatra is still constrained due to differences in the political system adopted by local political elites (bodi chaniago and koto piliang) and the dilemma in determining the democratic model chosen. Additionally, Rozi [22] also emphasizes that regional autonomy in West Sumatra fosters the formation of tendentious regional regulations that can trigger acts of discrimination between religions and polarizing conflicts in a pluralistic society.

In recent years, the Indonesian government has indeed been focusing on democratic practices in the province of West Sumatra. For example, in the statement of the head of the People's Representative Council, Puan Maharani, hopes that West Sumatra province will become a "supporter of the Pancasila state" [23]. Puan's statement immediately became a polemic among the people of West Sumatra and led to a request to become a Special Region of Minangkabau [24]. This tension indicates hidden friction between the central government and the West Sumatra local government.

At last, this research seeks to fill in the gaps in how the portrait of democracy in West Sumatra province is from a reasonably authentic point of view, namely linguistic analysis. The scientific interest in the study of news discourse related to the implementation of democracy is explained by the need for the interpretation of discourse in mass media texts that consider the Pragmatic guidelines of discourse producers, Syntax analysis models, and Semantic approaches. The main concern of this research is focused on the informative utterances presented in the discourse of the Singgalang newspaper headline as the party actively involved in conveying the situation and practice of democracy in West Sumatra on an ongoing basis. The research source is the coverage of the Singgalang newspaper, which was independently collected and documented throughout the 2016 publication year.

\section{Methods}

The discourse analysis in this paper applies a critical paradigm - this approach positions discourse as power, which represents the relationships that occur in society.The critical paradigm also considers discourse as a form of social practice [25].A discourse producer always has a discourse objective in social practice, including maintaining, exercising, or seizing power. To operate this, the discourse practice will display ideological effects, namely producing and reproducing unequal power relations between social classes, such as the government and the people, or the majority and minority groups. 


\subsection{Method of Collecting Data}

The data source in this study was a regional scale printed newspaper called "Singgalang," which was published throughout 2016. The research focuses its reading on the news containing violations of democracy summarized in the news containing $5 \mathrm{~W}+1 \mathrm{H}$. After reducing the data, categorization was carried out in the data table containing aspects of democracy calculated by BPS, such as aspects of Civil Liberties and aspects of Political Rights. To get the substance of the newspaper's coverage, content analysis is carried out to describe the news data into a more straightforward understanding. A conclusion was drawn whether mass media coverage could show a portrait of the implementation of democracy in the province of West Sumatra.

\subsection{Theoretical Framework}

The analysis in this study is focused on the linguistic aspect of the news, which contains a portrait of the implementation of democracy in West Sumatra. In getting a precise and comprehensive meaning, then this study uses the Critical Discourse Analysis platform offered by Sawirman [26]. Sawirman named the theory BREAK, an acronym for Basis, Relationship, Equilibrium, Actualization, and Sustainability of a discourse. This study only applied the Configuration analysis feature, which can uncover the internal structure of discourse through micro linguistic feature analysis.

Configuration Analysis is realized through three multilevel work steps in this instance, Analysis of Form, Essence, and Spirit. Form analysis seeks to uncover linguistic forms in the discourse. In this case, syntactic or semantic theories will be used as analysis tools. Essence analysis seeks to capture messages, meanings, or ideas from a discourse. Spirit analysis aims to reveal the motives, goals, orientation, or motivation of the analyzed discourse. Through a series of stratified and eclectic analyzes, it is hoped that the problems of this research can be explained in detail and depth.

\section{Data Analysis Method}

According to Van Dijk [27], the primary concern of Critical Discourse Analysis (CDA) is to analyze the language used in discourse to highlight the sources of power, domination, and inequality with particular reference to social, political, and historical contexts. In addition, this study also applies the opinion of Wodak [28], which states that texts are never isolated. Every text must have a connection with other texts in history. The links between these texts will clarify the meaning and position of the power relations in discourse.

The main object of analysis is the ideological structure of the newspaper headline. The ideology presented in the mass media sometimes describes objectivity and sometimes subjectivity [29]. However, news headlines often expose ongoing social representations and get more attention from audiences than full news articles. Hence, the impact is likely more significant for readers due to certain linguistic features which make them easy to remember and effective [30].

\section{Results and Discussion}

After conducting a preliminary analysis of the coverage of the Singgalang newspaper, 230 data were found containing news related to violations of democratic values in the province of West Sumatra. Most of the coverage was violations of political rights (e s- 
pecially Public Complaints) by the regional government in West Sumatra, totaling 165 cases. The coverage of violations of the aspects of democracy with the variable Freedom of Association and Assembly took the second position with 34 data. The variable of the slightest violation of democratic values was violent demonstrations, which amounted to 3 cases. For the overall result, see the findings table below.

Table 1. Findings of Democracy Violations in the province of West Sumatra in Singgalang Newspaper

\begin{tabular}{|c|c|c|c|}
\hline Aspect & Variable & Indicator & Frequency \\
\hline \multirow{5}{*}{$\begin{array}{l}\text { Civil } \\
\text { Freedom }\end{array}$} & \multirow[t]{2}{*}{$\begin{array}{l}\text { I. Freedom of As- } \\
\text { sembly and } \\
\text { Association }\end{array}$} & $\begin{array}{l}\text { 1. Threats of violence or the use } \\
\text { of force by government officials } \\
\text { that hinder freedom of assembly } \\
\text { and association }\end{array}$ & 34 \\
\hline & & $\begin{array}{l}\text { Threats of violence or the use } \\
\text { of violence by the community that } \\
\text { hinder freedom of association and } \\
\text { association }\end{array}$ & 9 \\
\hline & $\begin{array}{l}\text { III. Religious } \\
\text { Freedom }\end{array}$ & $\begin{array}{l}\text { 6. Actions or statements by gov- } \\
\text { ernment officials that restrict free- } \\
\text { dom or require people to practice } \\
\text { their religious teachings }\end{array}$ & 6 \\
\hline & $\begin{array}{l}\text { IV. Freedom from } \\
\text { Discriminations }\end{array}$ & $\begin{array}{l}\text { 9. Actions or statements by gov- } \\
\text { ernment officials that are discrimi- } \\
\text { natory in terms of gender, ethnicity, } \\
\text { or other vulnerable groups }\end{array}$ & 9 \\
\hline & & $\begin{array}{l}\text { 10. Threats of violence or the use of } \\
\text { violence by the community for rea- } \\
\text { sons of gender, ethnicity, or against } \\
\text { other vulnerable groups }\end{array}$ & 4 \\
\hline \multirow{2}{*}{$\begin{array}{l}\text { Political } \\
\text { Rights }\end{array}$} & \multirow{2}{*}{$\begin{array}{l}\text { VI. Political Par- } \\
\text { ticipation in Deci- } \\
\text { sion Making \& } \\
\text { Monitoring }\end{array}$} & 16. Violent demonstrations/strikes & 3 \\
\hline & & $\begin{array}{l}\text { 17. Public complaints regarding } \\
\text { governance }\end{array}$ & 165 \\
\hline
\end{tabular}

\subsection{Portrait of Democracy Violations in West Sumatra Province in the Headlines of Singgalang Newspaper}

The portrait of democracy violations referred to in the discussion this time is how the Singgalang newspaper displays its views on the violations of democracy in West Sumatra's province. This view of the mass media can imply many things, such as the ideological aspects that develop in society and the historical aspects that underlie an event, and the socio-cultural aspects that affect the dynamics of the society. In this case, the views of the mass media in Singgalang are dominantly reflected in the headlines.

The manifestation of views from mass media into news headlines can be realized through linguistic techniques such as word selection, syntax modification, variation of Semantic aspects, and other techniques. This is important to investigate because BPS (the authority that measures the Democracy Index) in carrying out the calculation and evaluation process entirely refers to the coverage in Singgalang newspaper. Therefore, the language discourse displayed in the news text of Singgalang is closely related to the portrait of the implementation of democracy in the province of West Sumatra.

The first discourse discussed was the variable of Public Complaints. This discourse appears with the highest frequency in the headlines. Some of the data that can be observed 
are as follows:

(1) Masyarakat Keluhkan Pilkada Kurang Semarak (I17, S:4/1/16)

People complained about spiritless regional election.

(2) Keluarga Korban Pengeroyokan Datangi Kantor DPRD Agam (Id17, S:2/1/16)

The families of the beating victims came to the DPRD Office of Agam.

(3) Warga Katiagan Kecewa Pembangunan Jembatan Gagal (Id17, S:22/1/16)

The residents of Katiagan were disappointed at the failed bridge construction.

In general, the discourse of Public Complaints in the mass media text is manifested in a transitive structure. It means that the structure requires the presence of an object for the action caused by the predicate. In data (1) and (2), the Objects in question are 'Spiritless local election' and 'the DPRD Office of Agam.' In data (3), the Object in question is topicalized and fronting in the phrase 'failed bridge construction (3)'.

The existence of the elements $(\mathrm{S})$ subject and $(\mathrm{O})$ object in the discourse structure above should be parallel to the clarity of the predicate. However, as stated in the data above, the (P)predicate expected to explain the activity, condition, nature, status, characteristics, or identity of the Subject cannot carry out their duties. The (P)predicates offered in the structure are 'complained' (1), 'came to' (2), and 'disappointed' (3). The three predicates have an obscure effect on the activities chosen by the Subject.

Linguistic technique in predicate-blurring can be categorized as self-censorship carried out by the mass media itself. This practice is quite common in Indonesia, considering past experiences in the New Order era. This is a form of 'responsibility of the press in 'national development and improvement [31], [32]. Media owners are interested in maintaining the smooth running of the business and political aspects through the use of their influence and power to obstruct journalists' freedom to report news [33]. The above argument is also supported by Oktavianti's findings [34], which states that the mass media in Indonesia can never be separated from the dominant hegemony, i.e., the State ideology.

In order to achieve the essence of the Public Complaints discourse, the analysis is focused on how the media obscures diction on the predicate function. The vagueness of diction that occupies the Predicate signals a message of doubt. This doubt comes from two premises: the ignorance of the public in the bureaucratic process or the disobedience of citizens (as the injured party) to the democratic mechanism in Indonesia. As in the example predicates 'complained' (1) and 'disappointed' (3), the Subject is described as doing unproductive activities, which do not impact changing the Subject's fate. This more likely stems from the Subject's ignorance of the matter at issue rather than bureaucratic defiance.

The state of 'complaint' and 'disappointment' in the predicate above is a manifestation of the frustration of the Subject (citizen) in the current bureaucratic process in Indonesia. Pratikno [35] claims that the practice of bureaucracy in Indonesia since the New Order era has indeed been far from efficient, requiring significant reforms. However, this issue is rarely found in mass media reports because it can impact national stability and disrupt nation-building and development. After the New Order, the revered bureaucratic reforms have not shown satisfying results [36]. This fact shows that there is a spirit of impasse in Public Services, especially in West Sumatra.

Another discourse that appears with the second-highest frequency is the violation of Freedom of Assembly and Association. The data obtained are as follows: 
(1) Main Game Play Station, 21 Pelajar Diamankan (I1, S:4/2/16)

Playing PlayStation games, 21 students were secured

(2) 39 Muda-mudi Terjaring (I1, 29/2/16)

39 spouse were trapped

(3) Dua Sejoli Digrebek di Bukit Lampu (I1, 26/3/16)

A Lovebird was raided in Bukit Lampu

The most prominent linguistic form in the above data is the passive-intransitive structure. Passive structures are structures that have changed, i.e., swap position between Subject and Object. For example, the actual Objects in the data above are 21 students, 39 young people, two lovebirds. However, in the headline of the Singgalang newspaper, these three objects are pushed forward enable them as the topic of discussion in this structure.

Furthermore, the predicate function filled with intransitive verbs indicates that the Subject (Doer) presence in this structure is optional (may be present or not). However, in the news headline from the data above, the Subject (Doer) functions as the actor of events such as 'being secured,' 'trapped,' 'raided,' experiencing deletion, or being hidden. This technique is used in order to emphasize the function of the Object rather than the Subject itself.

The essence of the discourse found in the above form is the complete blame for the victim (victim-blaming). The prioritization of the object element in the sentence structure above aims to entirely place the blame on the Object (the citizen) who is being prosecuted. This is then supported by the absence of the Subject element (legal apparatus) through the omission process. With this linguistic mechanism, readers will be directed to a particular perception where the local government, through its apparatus, has carried out its duties as well as possible, in this case taking action against citizens who violate the law.

Techniques of distorting facts and demonstrating the weak and the losers like this were the standard methods often exemplified by the former New Order government. For example, they refer to the massacre of people accused of being communists in 1966-70 [37]. At that time, millions of lives were humiliated and executed in public without proper trial [38]. By highlighting the mistakes of those considered to have violated the rules and norms, repressive actions by government officials (even though they violate human rights) can find moral justification.

The spirit found in the portrait of Freedom of Assembly and Association above is the open display of power by local government. The banal action of repression above shows the unbalanced portion of power between citizens and the government. This is later intended to create knowledge in the discipline to form fear in the community [39]. Through reporting techniques like this, the Singgalang newspaper suggests that the Subject of the perpetrator-the state apparatus-is free and active in carrying out tasks on orders from their superiors. The imposition of rules on the (patient) Object is normalized due to the unlimited authority of local government administrators.

\subsection{West Sumatra Government's Handicap: Bureaucratic Stalemate and Repres- sion of Human Rights}

Based on the analysis description above, it can be mapped the causes and motives for violating democracy in West Sumatra province, notably the variables of Public Complaints and Violations of Freedom of Association and Association. The entries in this table are 
based on the findings from the analysis of the Form, Essence, and Spirit of the discourse.

Table 2. Causes and Motives for Democracy Violations in the Singgalang Newspaper

\begin{tabular}{lll}
\hline Feature & Public Complaints & $\begin{array}{l}\text { Freedom of Assembly and Associa- } \\
\text { tion }\end{array}$ \\
\hline Form & Transitive Structure & Passive-Intransitive Structure \\
\hline Essence & $\begin{array}{l}\text { Ignorance of bureaucratic } \\
\text { processes }\end{array}$ & The complete blame for the victim \\
\hline Spirit & Public service deadlock & An open display of power \\
\hline
\end{tabular}

The lack of public knowledge in the bureaucratic process is the main factor causing a deadlock in public services recorded in the Public Complaints discourse. The ignorance of most people in Indonesia in recognizing, understanding, and implementing the bureaucratic process in the state is one of the significant homework in the bureaucratic reform agenda in Indonesia [40]. The closure of access to information on a large scale during the New Order era significantly resulted in the unclear action chosen by the community, which was reflected in an ambiguous Predicate.

In the second discourse, an open display of power is the motivation behind the violation of the freedom of association and association. Citizens who only make minor mistakes and in private areas (such as sexual activity, wandering around, playing games) are immediately subject to aggressive repression by law enforcement. This is motivated by a motive where the government will not tolerate the slightest mistake of citizens to maintain national stability and security [41].

\section{Conclusion}

This study discusses the portrait of democracy in West Sumatra province in the discourse of the local newspaper headlines. The results of this study indicate that the headline of the Singgalang newspaper can draw violations of democratic values in the province of West Sumatra. As in the case of Public Complaints, the Singgalang newspaper displays news headlines that show the motive for the impasse in Public Services by showing the confusion of the citizen in the bureaucratic process, which is reflected in the selection of a vague predicate. A similar manner also applies to the portrait of violations of the Freedom of Association and Association, where the headline of the Singgalang newspaper demonstrates how the local government performs an open show of power to citizens through the accentuation of Objects that are considered guilty of passive-intransitive sentence structure.

The findings of this study indirectly support the results of the BPS recording related to the Democracy Index in the province of West Sumatra. However, this study has limitations where it only takes a small part of the various elements measured to determine the level of democracy implementation in West Sumatra. In general, Critical Discourse Analysis allows language researchers to reveal ideologies, social structures, power relations in texts that appear normal and uncomplicated.

\section{Acknowledgment}

The author would like to thank the Director-General of RISTEK-BRIN and LP2M of the State University of Padang, who have provided financial support for the work and publication of this research. 


\section{References}

1. Heinze, E., \& Freedman, R. (2010). Public awareness of human rights: distortions in the mass media. The International Journal of Human Rights, 14(4), 491-523

2. Henry, F., \& Tator, C. (2002). Discourses of domination: Racial bias in the Canadian English-language press. Toronto, ON, Canada: University of Toronto Press

3. Kiousis, S. (2001). Public trust or mistrust? Perceptions of media credibility in the information age. Mass Communication \& Society, 4(4), 381-403.

4. Sevenans, J. (2018). How mass media attract political elites' attention. European Journal of Political Research, 57(1), 153-170

5. Adam, A. B. (1995). The Vernacular Press and the Emergence of Indonesian Consciousness (1855-1913). Ithaca, NY: Cornell University Press.

6. Anderson, B. (2016). Imagined communities: Reflections on the origin and spread of nationalism. London, England: Verso Books.

7. Hill, D. T. (2010). Journalism and politics in Indonesia: A critical biography of Mokhtar lubis (1922-2004) as editor and author. London, England: Routledge.

8. Gazali, E. (2003). Negotiating public and community media in post-Suharto Indonesia. Javnost - The Public, 10(1), 85-100.

9. Hidayat, D. N., Gazali, E., Suwardi, H., \& Ishadi, S. K. (2000). Pers dalam Revolusi Mei: Runtuhnya Sebuah Hegemoni. Jakarta: Gramedia.

10. Gazali, E. (2002). The Suharto regime and its fall through the eyes of the local media. Gazette, 64(2), 121-140.

11. Kitley, P. (2008). "Civil society and the media in Indonesia." In A. Azra \& W. Hudson (Eds.), Islam beyond conflict: Indonesian Islam and Western political theory. Burlington: Ashgate Publishing.

12. Ashaf, A. F. (2020). Sejarah Bredel 1994: Suara Pers Indonesia atas Pembredelan Tempo, Editor, dan Detik. Lampung: Pusaka Media.

13. Tapsell, R. (2018). Media power in Indonesia: Oligarchs, citizens, and the digital revolution. London, England: Rowman \& Littlefield International.

14. BPS. (2017). Berita Resmi Statistik No. 51/09/13/Th. XX, 15 September 2017 tentang IDI Provinsi Sumatera Barat Tahun 2016.

15. Elfisha, M. (2019, August 7). Gubernur Sumbar: Variabel indeks demokrasi justru tidak demokratis. Retrieved April 30, 2021, from ANTARA website: https://www.antaranews.com/berita/999148/gubernur-sumbar-variabel-indeks-demokrasi-justrutidak-demokratis

16. CNN Indonesia. (2019, December 21). Menag Sebut Larangan Natal di Dharmasraya Kesepakatan Bersama. Retrieved April 30, 2021, from cnnindonesia.com website: https://www.cnnindonesia.com/nasional/20191221182138-20-459005/menag-sebut-larangan-na tal-di-dharmasraya-kesepakatan-bersama

17. Wajib jilbab bagi siswi non-Muslim di Padang: "Sekolah negeri cenderung gagal terapkan kebhinekaan.” (2021, January 26). BBC. Retrieved from https://www.bbc.com/indonesia/indonesia-55806826

18. von Benda-Beckmann, F., \& von Benda-Beckmann, K. (2016). Political and legal transformations of an Indonesian polity: The nagari from colonization to decentralization. Cambridge, England: Cambridge University Press.

19. Perda Provinsi Sumbar no.9 Tahun 2000 tentang Pokok-pokok Pemerintahan Nagari. (2000).

20. Blackwood, E. (2001). Representing Women: The Politics of Minangkabau Adat Writings. The Journal of Asian Studies, 60(1), 125-149.

21. Valentina, T. R., Kusdarini, \& Putera, R. E. (2011). The State Versus Local Elite Conflict in A Transitional Phase of Democracy. Bisnis \& Birokrasi: Jurnal Ilmu Administrasi Dan Organisasi, 18(3), 210-218.

22. Rozi, S. (2008). "Relasi Agama dan negara dalam Konteks Politik Lokal (Dinamika Formalisasi Islam dalam Perda Syariah di Sumatra Barat”. Politik Identitas: Agama, Etnisitas, Dan Ruang/Space Dalam Dinamika Politik Lokal Di Indonesia Dan Asia Tenggara. Salatiga: Yayasan Percik.

23. Putri, B. U. (2020, September 2). Puan Maharani Ingin Sumbar Dukung Pancasila, Ini Penjelasan Sekjen PDIP. Retrieved April 30, 2021, from TEMPO.CO website: 
https://nasional.tempo.co/read/1382078/puan-maharani-ingin-sumbar-dukung-pancasila-ini-penj elasan-sekjen-pdip/full\&view $=$ ok

24. Paath, C. K. Y. (2021, March 13). DPD: Sumatera Barat Layak Menjadi Daerah Istimewa Minangkabau. Retrieved April 30, 2021, from BeritaSatu.com website: https://www.beritasatu.com/politik/745319/dpd-sumatera-barat-layak-menjadi-daerah-istimewaminangkabau

25. Fairclough, N. (2001). The dialectics of discourse. Textus, 14(2), 3-10.

26. Sawirman. (2014). E135 Reader: Media Meliput Teror (edisi Osama Bin Laden). Padang: Pusat Studi Ketahanan Nasional dan Universitas Andalas.

27. van Dijk, T. A. (2012). Ideology: A multidisciplinary approach. London, England: SAGE Publications.

28. Wodak, R. (2001). Methods of critical discourse analysis. Thousand Oaks, CA: SAGE Publications.

29. Nawaz, S., Bilal, A. H., Kalsoom, M., Fayyaz, Z., \& Nayyar, H. (2003). Media discourse and their implicit ideologies. Journal of Social Science and Humanities, 2(2), 328-337.

30. Develotte, C., \& Rechniewski, E. (2001). Discourse Analysis of Newspaper Headlines: A Methodological Framework for Research into National Representations. Web Journal of French Media Studies, 4(1), 1-16.

31. Suharto. (1989). "The role of the press in national development." In A. Mehra (Ed.), Press systems in ASEAN states. Singapore: AMCRIC.

32. Romano, Angela. (2012). "Asian journalism: news, development and the tides of liberalization and technology." In A. Romano \& M. Bromley (Eds.), Journalism and Democracy in Asia (pp. 15-28). Routledge.

33. Tapsell, R. (2012). Old tricks in a New Era: Self-censorship in Indonesian journalism. Asian Studies Review, 36(2), 227-245.

34. Oktavianti, R. (2018). Reportase dalam Hegemoni Pemerintah dan Media: Studi Kasus Jurnalis Kepresidenan Era Soeharto dan Joko Widodo. Jurnal Komunikasi Indonesia, 5(1). doi:10.7454/jki.v5i1.8331

35. Pratikno. (2015). Urgensi reformasi basis kekuasaan birokrasi di Indonesia. JKAP (Jurnal Kebijakan Dan Administrasi Publik), 2(1), 13-26.

36. Mcleod, R. H. (2005). The struggle to regain effective government under democracy in Indonesia. Bulletin of Indonesian Economic Studies, 41(3), 367-386.

37. Zed, M. (2002). Hidden history: Sejarah kebrutalan dan kejahatan negara melawan isu-isu dan strategi kemanusiaan dalam konteks sejarah Indonesia. Jurnal Demokrasi Dan HAM, 2(1), 6-37.

38. Anderson, B. R. O. G. (Ed.). (2000). Violence and the state in Suharto's Indonesia. Ithaca, NY: Southeast Asia Program Publications, Cornell University.

39. Foucault, M. (1980). Power/knowledge: Selected interviews and other writings, 1972-1977. New York, NY: Pantheon Books.

40. Romli, L. (2008). Masalah reformasi birokrasi. Civil Service Journal, 2(2), 1-7.

41. Rajab, B. (2004). Negara Orde Baru: Berdiri di atas sistem ekonomi dan politik yang rapuh. Sosiohum, 6(3), 182-202. 